\title{
«Styles, genres, auteurs» 16
}

\section{Maria Colombo Timelli}

\section{Q OpenEdition}

\section{Journals}

\section{Édition électronique}

URL : http://journals.openedition.org/studifrancesi/9902

DOI : 10.4000/studifrancesi.9902

ISSN : 2427-5856

\section{Éditeur}

Rosenberg \& Sellier

\section{Édition imprimée}

Date de publication : 1 août 2017

Pagination : 341

ISSN : 0039-2944

\section{Référence électronique}

Maria Colombo Timelli, « «Styles, genres, auteurs» 16 », Studi Francesi [En ligne], 182 (LXI | II) | 2017,

mis en ligne le 01 août 2017, consulté le 06 janvier 2021. URL : http://journals.openedition.org/ studifrancesi/9902 ; DOI : https://doi.org/10.4000/studifrancesi.9902

Ce document a été généré automatiquement le 6 janvier 2021.

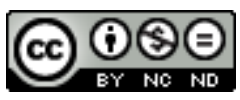

Studi Francesi è distribuita con Licenza Creative Commons Attribuzione - Non commerciale - Non opere derivate 4.0 Internazionale. 
«Styles, genres, auteurs» 16

Maria Colombo Timelli 


\section{RÉFÉRENCE}

«Styles, genres, auteurs» 16, 2016.

1 Au programme pour l'Agrégation en Lettres et en Grammaire de 2017, le Livre du Duc des vrais amants, œuvre peu connue de Christine de Pizan éditée en 2013 seulement (par Dominique DEMARTINI et Didier LECHAT, Paris, Champion Classiques Moyen Age), suscite nécessairement un intérêt renouvelé chez les critiques. Nous signalons donc ici deux articles parus dans le recueil que l'UFR de Langue Française de la Sorbonne a consacré aux textes au concours.

Dans le premier, Sarah DELALE se concentre sur ce qu'elle appelle la «théâtralisation» de l'amour courtois, et plus en particulier sur les procédés stylistiques et jeux de langage par lesquels Christine représente l'amour entre le Duc et la Dame: les personnifications, dont elle analyse le fonctionnement dans les différents contextes, Jalousie et Danger notamment, assument le statut de «personnages» dans un récit qui ne se transforme pas pour autant en roman allégorique (Faire le courtois: représentation, allégorisation et théâtralisation de l'amour dans "Le Livre du Duc des vrais amants", pp. 13-43).

Dans le second, Gabriella PARUSSA met en relief les caractéristiques les plus saillantes de la langue du Livre: aspects graphiques et phonétiques, traits morphologiques, syntaxe de la phrase et ordre des mots, lexique (mots rares, archaïques et régionaux), tout semble converger pour étayer une séparation assez nette entre parties en vers (narratives et lyriques) et insertions en prose (lettres). Les contraintes rimiques et rythmiques d'un côté, le but didactique et l'efficacité poursuivis de l'autre, s'avèrent ainsi être les critères qui ont présidé quelques choix de Christine. Plutôt donc qu'attribuer certains traits au sexe ou à l'origine italienne de la poétesse, on aurait tout intérêt à étudier la langue de Christine en rapport avec la production, en vers et en prose, de ses contemporains (La langue de Christine de Pizan: usages et contraintes génériques, pp. 45-65). 